\title{
Genotype Distribution of Vitamin D Receptor Polymorphisms among Indonesian Patients with Chronic Hepatitis B
}

\author{
Arfianti Arfianti*1, Athalah Sabillah Sumpena ${ }^{2}$, Fauzia Andrini Djojosugito ${ }^{3}$, \\ Dita Kartika Sari ${ }^{4}$, Ariza Julia Paulina ${ }^{5}$
}

\begin{abstract}
Background: Chronic hepatitis B is a necro-inflammatory of the liver parenchyma caused by hepatitis B virus (HBV) infection leading to liver cirrhosis and hepatocellular carcinoma (HCC). Genetic variants including single nucleotide polymorphisms (SNPs) within genes regulating immune response may contribute to the progression of chronic hepatitis B (CHB) infection. This study aimed to examine the genotype distribution of vitamin D receptor (VDR) polymorphism among patients with $\mathrm{CHB}$ infection and to study its association with the development of cirrhosis and hepatoma.

Methods: This cross-sectional study analysed $75 \mathrm{CHB}$ patients, consisting of $36 \mathrm{CHB}$ patients without cirrhosis, $25 \mathrm{CHB}$ patients with cirrhosis, and $14 \mathrm{CHB}$ patients with hepatoma. VDR polymorphism was examined using the Amplification Refractory Mutation System Polymerase Chain Reaction (ARMS-PCR) method.

Results: Alanine aminotransferase (ALT) and alpha fetoprotein (AFP) levels did not show any significant differences between study groups, but albumin levels in CHB patients with cirrhosis and hepatoma were significantly lower than CHB patients without cirrhosis $(p<0.05)$. In contrast, the bilirubin levels in CHB patients with cirrhosis was higher than in CHB patients' cirrhosis. The most common genotypes of VDR polymorphisms were Ff (57.3\%), TT (72\%), aa (48\%) and bb (74.7\%) for Fok1, Taq1, Apa1 and Bsm1 respectively. There was no significant different in the genotype distribution of VDR polymorphism between CHB patients without cirrhosis and CHB with cirrhosis or hepatoma.
\end{abstract}

Conclusions: This study suggest that VDR gene polymorphism may not contribute to the progression of CHB infection.

Keywords: Cirrhosis, Hepatitis B, Hepatoma, Polymorphism, Vitamin D Receptor.

\section{Introduction}

Hepatitis B virus (HBV) infection is a major health problem affecting $>250$ million people globally and causes 880000 death annually (1). The prevalence of hepatitis B surface antigen (HBsAg) in Indonesia is $7.1 \%$, indicating a moderate endemicity for HBV infection. HBV infection that occurs during adults generally trigger an effective immune response, resulting in resolution of acute infection (2). However, 95\% of $\mathrm{HBV}$ exposure during perinatal will result in chronic HBV infection. Chronic hepatitis B (CHB) confers a substantial risk for liver cirrhosis and hepatocellular carcinoma (HCC), the latest is the second-leading cause of cancer-related death worldwide. Recently, accumulating evidence

1: Department of Medical Biology, Faculty of Medicine, Universitas Riau, Pekanbaru, Indonesia.

2: Undergraduate of Faculty of Medicine, Universitas Riau, Pekanbaru, Indonesia.

3: Department of Microbiology, Faculty of Medicine, Universitas Riau, Pekanbaru, Indonesia.

4: Department of Anatomy, Faculty of Medicine, Universitas Riau, Pekanbaru, Indonesia.

5: Department of Clinical Pathology, Faculty of Medicine, Univensitas Riau, Pekanbaru, Indonesia.

*Corresponding author: Arfianti Arfianti; Tel: +62 8117066001; E-mail: Arfianti@unri.ac.id.

Received: 9 Nov, 2020; Accepted: 13 Dec, 2020 
based on single nucleotide polymorphisms (SNPs) have suggested the important role of host genetic factors on the risk for liver cirrhosis and HCC among patients with $\mathrm{CHB}(3,4)$.

Hepatitis B virus is known as a non-cytopathic virus, which means that the inflammatory process and liver damage is not due to viral invasion but depend on the complex interaction between viral replication and host immune response (5). The adaptive immune responses governed by $\mathrm{T}$-cell responses have been crucial in the persistence of chronic HBV infection. It has been shown that patients chronically infected with HBV demonstrated impaired T-responses (6-8).

Vitamin D is a fat soluble hormone that has important roles as immune modulator. Epidemiological studies suggest association between vitamin $\mathrm{D}$ deficiency and higher incidence of autoimmune diseases (9), cancer (10), metabolic (11) and inflammatory diseases including infection with HBV $(12,13)$. The cellular actions of vitamin $\mathrm{D}$ are mediated by vitamin D receptors (VDR), a superfamily of nuclear transcription factor that is expressed in many cell types including various immune cells such as antigen-presenting cells, T cells, B cells and monocytes (14).

Vitamin D receptor gene is located on chromosome 12q12-q14. Previous studies have reported several SNPs within VDR gene that may affect its function in regulating the expression of target genes. Vitamin D receptors gene polymorphisms have been reported to be associated with diseases such as rheumatoid arthritis (15), tuberculosis (16), Graves' disease (6) and cancer (17). This study aimed to examine the distribution of genotype and allele of VDR polymorphisms among patients with $\mathrm{CHB}$ and analyse its association with risk for liver cirrhosis and hepatoma.

\section{Materials and Methods Study subjects}

This study examined $75 \mathrm{CHB}$ patients who were recruited from the Internal Medicine Department of the Arifin Achmad Hospital, Riau Province between March-September 2019. Of these 75 patients, 36 subjects were $\mathrm{CHB}$ patients without cirrhosis, 25 subjects were CHB patients with cirrhosis and 14 subjects were $\mathrm{CHB}$ patients with hepatoma. Chronic hepatitis B was diagnosed based on HBsAg positivity for at least 6 months. Cirrhosis was diagnosed based on imaging (transient elastography and/or ultrasonography) and clinical signs, including oesophageal varices and ascites. Hepatoma was determined by computed tomography and/or magnetic resonance imaging and $\alpha$-fetoprotein (AFP) levels. Written informed consent was obtained from all study participants after receiving adequate information about the study. The study protocol was approved by the Ethical Committee of Medical and Health Research, Faculty of Medicine, Universitas Riau in accordance with the Helsinki Declaration. The inclusion criteria were $\mathrm{CHB}$ patients aged equal or more than 18 years while the exclusion criteria were co-infection with other virus infection including hepatitis $\mathrm{C}$ virus and hepatitis $\mathrm{D}$ virus infection. Levels of serum ALT, albumin, and bilirubin were measured using commercial kits.

\section{Genotyping of vitamin $D$ receptor (VDR) polymorphims}

Ten $\mathrm{mL}$ of venous blood was withdrawn from each study participants and immediately stored in ethylenediaminetetraceticacid (EDTA) tubes. The blood was then centrifuged at $2000 \mathrm{~g}$ for 5 minutes and the plasma stored at $-80{ }^{\circ} \mathrm{C}$ while the packed blood cells were stored at $-20{ }^{\circ} \mathrm{C}$ for DNA extraction. Genomic DNA was extracted using Wizard ${ }^{\circledR}$ Genomic DNA Purification kit (Promega Inc., Madison, WI, USA) according manufacturer's protocol. The VDR FokI T $>\mathrm{C}$ (rs 10735810), BsmI C >T (rs 1544410), ApaI G>T (rs7975232), and TaqI C>T (rs 731236) single nucleotide polymorphisms (SNPs) were determined by the Amplification Refractory Mutation System Polymerase Chain Reaction (ARMS-PCR) method using primers designed by Jafari et al (18). as presented in Table 1. Each sample was amplified twice using one specific allele (wild-type or mutant) and one common primer. The PCR reaction was carried out in a total volume of $25 \mathrm{uL}$ using GoTaq ${ }^{\circledR}$ Green Master Mix (Promega Inc., Madison, WI, USA) containing GoTaq ${ }^{\circledR}$ reaction buffer (pH 8.5), 200 $\mu \mathrm{M}$ dNTP, $1.5 \mathrm{mM}$ of $\mathrm{MgCl} 2$ and $5 \mathrm{uL}$ of genomic DNA. The thermal cycler conditions 
were as follows: initial denaturation at $95{ }^{\circ} \mathrm{C}$ for 2 minutes, 29 cycles of denaturation at $95{ }^{\circ} \mathrm{C}$ for 25 seconds, annealing at $58{ }^{\circ} \mathrm{C}$ for 30 seconds and extension at $72{ }^{\circ} \mathrm{C}$ for 1 minute; and final extension at $72{ }^{\circ} \mathrm{C}$ for 5 minutes. PCR products were subjected to electrophoresis on $2 \%$ agarose gel containing GelRed® Nucleic Acid Gel stain (Biotium, Fremont, CA, USA) submerged in 1x Tris Acetate EDTA (TAE) buffer at 75 volts for 40 minutes. PCR fragments were visualised in a UV GelDoc $^{\mathrm{TM}}$ (Bio-Rad, USA).

Table 1. Primers used to detect VDR polymorphisms (26).

\begin{tabular}{|c|c|c|}
\hline Primer sequences & Annealing temperature $\left({ }^{\circ} \mathrm{C}\right)$ & Amplicon size (bp) \\
\hline \multicolumn{3}{|l|}{ FokI (rs10735810) } \\
\hline FokI/F: 5'-TGGCCGCCATTGCCTCCG 3' & 62 & \\
\hline FokI/f: 5’- TGGCCGCCATTGCCTCCA 3' & 60 & 77 \\
\hline FokI/C: 5'- AGCTGGCCCTGGCACTGA 3' & 60 & \\
\hline \multicolumn{3}{|l|}{ BsmI (rs1544410) } \\
\hline BsmI/B: 5'-AGCCTGAGTACTGGGAATGT-3' & 60 & \\
\hline BsmI/b:5'- AGCCTGAGTACTGGGAATGC-3' & 62 & 534 \\
\hline BsmI/C:5'- GGGAGGGAGTTAGGCACC-3' & 60 & \\
\hline \multicolumn{3}{|l|}{ TaqI (rs731236) } \\
\hline TaqI/B:5'- CAGGACGCCGCGCTGATT-3' & 62 & \\
\hline TaqI/b:5'- CAGGACGCCGCGCTGATC-3'5' & 60 & 148 \\
\hline TaqI/C:5'-CCTCATTGAGGCTGCGCAG-3' & 62 & \\
\hline \multicolumn{3}{|l|}{ ApaI (rs7975232) } \\
\hline ApaI/A:5'- TGGGATTGAGCAGTGAGGT-3' & 58 & \\
\hline ApaI/a:5'- TGGGATTGAGCAGTGAGGG-3' & 60 & 229 \\
\hline ApaI/C:5'- CCTCATTGAGGCTGCGCAG-3' & 62 & \\
\hline \multicolumn{3}{|l|}{ Internal Control } \\
\hline DRBI-F 5'- TGCCAAGTGGAGCACCCAA 3' & 60 & 729 \\
\hline DRBI-R 5'-GCATCTTGCTCTGTGCAGAT 3' & 60 & \\
\hline
\end{tabular}

\section{Statistical analyses}

Categorical data are presented as proportion while numerical variable is presented as mean $\pm \mathrm{SD}$ (min-max). Chi-square test was used to examine group differences for genotype and allele frequencies of VDR polymorphisms. $\mathrm{p}<0.05$ was considered statistically significant. Statistical analyses were performed with SPSS statistic version 22 (IBM Corp., Armonk, NY, USA) for Mac.

\section{Results}

Demographic and clinical characteristic of study subjects

The demographic characteristics of study population are presented in Table 2. The mean age of study subjects was $45.37 \pm 13.26$ years (1873 years). Subjects consisted of $45(60 \%)$ males and $30(40 \%)$ females. Table 3 shows the comparison of liver function between $\mathrm{CHB}$, cirrhosis and hepatoma. The mean ALT levels did not differ significantly between $\mathrm{cHB}$, cirrhosis and hepatoma patients. However, albumin levels in CHB patients with cirrhosis $(3.1 \pm 0.7 \mathrm{~g} / \mathrm{dL})$ and $\mathrm{CHB}$ with hepatoma $(3.6 \pm 0.5$ $\mathrm{g} / \mathrm{dL})$ were significantly lower than those with CHB ( $p<0.05$ ). In contrast, albumin levels in CHB patients with cirrhosis were higher than CHB patients $(2.9 \pm 3.7$ vs. $1.5 \pm 3.3 \mathrm{mg} / \mathrm{mL}, \mathrm{p}<$ 0.05).

\section{VDR polymorphism}

Genotype distribution of VDR polymorphisms among study subjects is presented in Table 4. Of four VDR polymorphisms, bb (74.7\%), aa (48\%), TT $(72 \%)$ and Ff $(57.3 \%)$ were the most prevalent genotypes for BsmI, ApaI, TaqI, and FokI, respectively. Tables 5 and 6 show the genotype and allele frequencies of VDR polymorphisms among patients with $\mathrm{CHB}$. We found no significant difference in the genotype and allele frequencies between $\mathrm{CHB}$, cirrhosis and hepatoma patients. 
Table 2. Characteristic of study subjects.

\begin{tabular}{lll}
\hline Variable & $\mathrm{N}=75$ & $\%$ \\
\hline Age & & \\
Mean \pm SD (years) & $45.37 \pm 13.26$ & \\
Min-max (years) & $18-73$ & \\
Sex & & 60 \\
Male & 45 & 40 \\
Female & 30 & \\
Diagnosis & 36 & 48 \\
CHB without cirrhosis & 25 & 33.3 \\
CHB with Cirrhosis & 14 & 18.7 \\
CHB with hepatoma & CHB=Chronic hepatitis B
\end{tabular}

Table 3. Comparison of liver function tests among patients with CHB.

\begin{tabular}{llll}
\hline Variable & CHB & Cirrhosis & Hepatoma \\
\hline ALT $($ mean $\pm \mathrm{SD}, \mathrm{IU} / \mathrm{L})$ & $76.3 \pm 195.7$ & $53.4 \pm 43.1$ & $49.4 \pm 57.3$ \\
Albumin $(\operatorname{mean} \pm \mathrm{SD}, \mathrm{g} / \mathrm{dL})$ & $4.2 \pm 0.7$ & $3.1 \pm 0.7^{*}$ & $3.6 \pm 0.5^{*}$ \\
Bilirubin $($ mean $\pm \mathrm{SD}, \mathrm{mg} / \mathrm{dL})$ & $1.5 \pm 3.3$ & $2.9 \pm 3.7^{*}$ & $1.3 \pm 1.4$ \\
\hline
\end{tabular}

${ }^{*} \mathrm{p}<0.05$ vs. CHB using One-way ANOVA test.

Table 4. Genotypic distribution of VDR polymorphisms among chronic hepatitis B patients.

\begin{tabular}{lll}
\hline Genotype & $\mathbf{N}$ & \% \\
\hline BsmI & 5 & \\
BB & 5.7 \\
Bb & 14 & 18.7 \\
bb & 56 & 74.7 \\
ApaI & 12 & 16 \\
AA & 27 & 36 \\
Aa & 36 & 48 \\
aa & & \\
TaII & 54 & 72 \\
TT & 4 & 5.3 \\
Tt & 17 & 22.7 \\
tt & & \\
FokI & 24 & 32 \\
FF & 43 & 57.3 \\
Ff & 8 & 10.7 \\
ff & & \\
\hline
\end{tabular}

Table 5. VDR genotype frequencies among patients with chronic hepatitis B patients.

\begin{tabular}{|c|c|c|c|c|}
\hline Genotype & $\begin{array}{l}\text { CHB without } \\
\text { cirrhosis }(n=36)\end{array}$ & $\begin{array}{l}\text { CHB with } \\
\text { cirrhosis }(n=25)\end{array}$ & $\begin{array}{l}\text { CHB with } \\
\text { hepatoma }(n=14)\end{array}$ & $P$ value \\
\hline \multicolumn{5}{|l|}{ BsmI } \\
\hline $\mathrm{BB}$ & $2(40 \%)$ & $2(40 \%)$ & $1(20 \%)$ & 0.794 \\
\hline $\mathrm{Bb}$ & $8(57.1 \%)$ & $5(35.7 \%)$ & $1(7.1 \%)$ & \\
\hline $\mathrm{bb}$ & $26(46.4 \%)$ & $18(32.1 \%)$ & $12(21.4 \%)$ & \\
\hline \multicolumn{5}{|l|}{ ApaI } \\
\hline AA & $5(41.7 \%)$ & $3(25 \%)$ & $4(33.3 \%)$ & 0.577 \\
\hline $\mathrm{Aa}$ & $15(55.6 \%)$ & $8(29.6 \%)$ & $4(14.8 \%)$ & \\
\hline aa & $16(44.4 \%)$ & $14(38.9 \%)$ & $6(16.7 \%)$ & \\
\hline \multicolumn{5}{|l|}{ TaqI } \\
\hline $\mathrm{TT}$ & $26(48.1 \%)$ & $18(33.3 \%)$ & $10(18.5 \%)$ & 0.765 \\
\hline $\mathrm{Tt}$ & $3(75 \%)$ & $1(25 \%)$ & $0(0 \%)$ & \\
\hline $\mathrm{tt}$ & $7(41.2 \%)$ & $6(35.3 \%)$ & $4(23.5 \%)$ & \\
\hline \multicolumn{5}{|l|}{ FokI } \\
\hline $\mathrm{FF}$ & $14(58.3 \%)$ & $8(33.3 \%)$ & $2(8.3 \%)$ & 0.468 \\
\hline $\mathrm{Ff}$ & $18(41.9 \%)$ & $14(32.6 \%)$ & $11(25.6 \%)$ & \\
\hline $\mathrm{ff}$ & $4(50 \%)$ & $3(37.5 \%)$ & $1(12.5 \%)$ & \\
\hline
\end{tabular}


Table 6. Allele frequencies of VDR polymorphisms among patients with CHB.

\begin{tabular}{lllll}
\hline Allele & CHB $(\mathbf{n}=\mathbf{3 6})$ & Cirrhosis $(\mathbf{n}=\mathbf{2 5})$ & $\begin{array}{l}\text { Hepatoma }(\mathbf{n}= \\
\mathbf{1 4})\end{array}$ & p value \\
\hline BsmI & $12(50 \%)$ & $9(37.5 \%)$ & $3(12.5 \%)$ & 0.685 \\
$\mathrm{~B}$ & $60(47.6 \%)$ & $41(32.5 \%)$ & $25(19.9 \%)$ & \\
$\mathrm{b}$ & $25(49 \%)$ & $14(27.5 \%)$ & $12(23.5 \%)$ & 0.407 \\
ApaI & $47(47.5 \%)$ & $36(36.4 \%)$ & $16(16.1 \%)$ & \\
A & & $37(33 \%)$ & $20(17.9 \%)$ & 0.869 \\
$\mathrm{a}$ & $55(49.1 \%)$ & $13(34.2 \%)$ & $8(21.1 \%)$ & \\
TaqI & $17(44.7 \%)$ & $30(32.9 \%)$ & $15(16.6 \%)$ & 0.633 \\
T & & $20(33.9 \%)$ & $13(22.1 \%)$ & \\
t & $46(50.5 \%)$ & $\mathrm{p}<0.05$ vs. using Chi-square test. & \\
FokI & $26(44 \%)$ &
\end{tabular}

\section{Discussion}

Patients with persistence HBV infection are at increased risk for developing liver cirrhosis and HCC, depending on viral and host factors (5). In recent years, several studies have shown that SNPs of VDR gene identified by allelic variation in restriction enzyme sites are associated with increased susceptibility of liver cirrhosis and liver cancer development among CHB patients in various global population. The present study analysed the genotype and allele frequencies of VDR polymorphisms among Indonesian patients with CHB. Our results showed that bb, aa, TT, and Ff genotype were the most frequent genotypes for BsmI, ApaI, TaqI, and FokI, respectively. Few studies have been conducted to examine the genotype distribution of VDR gene in Indonesian population. Setiabudiawan et al (19). reported that bb, AA, TT, and Ff/ff were the most prevalent genotype with regard to VDR gene, indicating that ApaI polymorphism has more genetic variation within Indonesian population that BsmI, TaqI, and FokI. Previous studies have reported different genotype distributions including $\mathrm{BB}, \mathrm{AA}, \mathrm{TT}$, and $\mathrm{Ff}$ in Vietnamnese (20) and Bb, Aa, TT, Ff in German population (21). This suggest that genetic variations within ApaI and BsmI sites are exist between population.

Furthermore, we found no significant difference in the distribution of VDR gene polymorphism between $\mathrm{CHB}$ patients without cirrhosis, with cirrhosis and with hepatoma. There have been conflicting results regarding the association between VDR polymorphisms and the progression of HBV-related liver disease. Previous study demonstrated that FokI gene polymorphism $(\mathrm{C}>\mathrm{T})$ were linked to increased risk for HCC development in Egyptian population infected with $\mathrm{HBV}(22)$. Similarly, FokI polymorphism was significantly associated with risk for developing HCC in a Chinese population with chronic HBV infection (23) and showed better therapeutic response in $\mathrm{CHB}$ patients received pegylated interferons (PEG-INFs) (24). A recent meta-analysis further supports the correlation of FokI polymorphism with HBV infection and liver disease progression (25). While a recent study reported that ApaI polymorphism was associated with the clinical picture and disease progression in Vietnamnese population infected with HBV (20).

Vitamin D is an important immune modulator by binding with vitamin $\mathrm{D}$ receptors (VDR). VDR is a member of intranuclear receptor family that acts as a transcription factor. Several cells of the immune system such as dendritic cells, macrophages, $\mathrm{T}$ and $\mathrm{B}$ lymphocytes are known to express VDR on the cell membrane. Vitamin D has been reported to modulate the activity of $>900$ genes (14). These data further strengthen the role of vitamin $\mathrm{D}$ in the pathogenesis of malignant diseases, metabolic 
diseases and infections, including $\mathrm{HBV}$ infection.

The gene encoding vitamin $\mathrm{D}$ receptor is located on chromosome 12 and consists of 9 exons. There are four major polymorphic sites within the VDR gene: intron 8 consists BsmI (rs1544410) and ApaI (rs7975232) polymorphisms, exon 9 contains TaqI (rs731236) polymorphism, which is created by a silent $\mathrm{T}$ to $\mathrm{C}$ substitution, and exon 2 has FokI (rs 10735810) polymorphism, producing a protein variant with three additional amino acids at the amino terminus resulted from an alternative translation initiation (21).

To our knowledge, this is the first study to investigate the association between VDR gene

\section{References}

1. World Health Organization. Global Hepatitis Report, 2017 [Internet]. WHO. 2017. 62 p. Available from: https://apps.who.int/iris/handle/10665/255016.

2. H Muljono D. Epidemiology of Hepatitis B and $\mathrm{C}$ in Republic of Indonesia. Euroasian $\mathrm{J}$ Hepatogastroenterol. 2017;7(1):55-59.

3. Zhang Z, Wang C, Liu Z, Zou G, Li J, Lu M. Host Genetic Determinants of Hepatitis B Virus Infection. Front Genet. 2019;10:696.

4. Zhang J, Liu L, Lin Z, Ji X, Pi L, Lin X, et al. SNP-SNP and SNP-environment interactions of potentially functional HOTAIR SNPs modify the risk of hepatocellular carcinoma. Mol Carcinog. 2019;58(5):633-642.

5. Trepo C, Chan HL, Lok A. Hepatitis B virus infection. Lancet. 2014;384(9959):2053-63.

6. Meng S, He S, Jiang W, Xiao L, Li D, Xu J, et al. Genetic susceptibility to autoimmune thyroid diseases in a Chinese Han population: Role of vitamin D receptor gene polymorphisms. Ann Endocrinol (Paris). 2015;76(6):684-9.

7. Meng Z, Chen Y, Lu M. Advances in Targeting the Innate and Adaptive Immune Systems to Cure Chronic Hepatitis B Virus Infection. Front Immunol. 2019;10:3127.

8. Yang PL, Althage A, Chung J, Maier H, Wieland S, Isogawa M, et al. Immune effectors required for hepatitis B virus clearance. Proc Natl Acad Sci U S A. 2010;107(2):798-802. polymorphism and HBV infection within Indonesian population. The limitation of this study was the small size of study subjects enrolled and lack of clinical data related to cirrhosis and HCC severity. So, further studies with larger samples are required to confirm the role of VDR gene polymorphisms on the risk for liver cirrhosis and $\mathrm{HCC}$ among $\mathrm{CHB}$ patients.

\section{Acknowledgements}

The authors thank Dr. Dasril Effendi, SpPDKGEH for helping with the patient recruitment. This study was funded by Research Grant from Faculty of Medicine, Universitas Riau 2020 (Grant no. 2322-3480).

9. Bizzaro G, Antico A, Fortunato A, Bizzaro N. Vitamin $\mathrm{D}$ and Autoimmune Diseases: Is Vitamin D Receptor (VDR) Polymorphism the Culprit?. Isr Med Assoc J. 2017;19(7):438-443.

10. Mondul AM, Weinstein SJ, Layne TM, Albanes D. Vitamin D and Cancer Risk and Mortality: State of the Science, Gaps, and Challenges. Epidemiol Rev. 2017;39(1):28-48.

11. Zhai N, Bidares R, Makoui MH, Aslani S, Mohammadi P, Razi B, et al. Vitamin D receptor gene polymorphisms and the risk of the type 1 diabetes: a meta-regression and updated metaanalysis. BMC Endocr Disord. 2020;20:121.

12. Farnik H, Bojunga J, Berger A, Allwinn R, Waidmann $\mathrm{O}$, Kronenberger $\mathrm{B}$, et al. Low vitamin $\mathrm{D}$ serum concentration is associated with high levels of hepatitis B virus replication in chronically infected patients. Hepatology. 2013;58(4):1270-6.

13. Gao W, Wang R, Wang X, Wu H, Wang Y, $\mathrm{Lu} X$, et al. Vitamin D serum levels and receptor genetic polymorphisms are associated with hepatitis B virus and HIV infections and IFN- $\lambda$ levels. Biomark Med. 2017;11(9):733-740.

14. Sassi F, Tamone C, D'amelio P. Vitamin D: Nutrient, hormone, and immunomodulator. Nutrients. 2018;10(11):1656.

15. Tizaoui K, Hamzaoui K. Association between VDR polymorphisms and rheumatoid arthritis disease: Systematic review and updated 
meta-analysis of case-control studies. Immunobiology. 2015;220(6):807-16.

16. Salimi S, Farajian-Mashhadi F, Alavi-Naini R, Talebian G, Narooie-Nejad M. Association between vitamin $\mathrm{D}$ receptor polymorphisms and haplotypes with pulmonary tuberculosis. Biomed Rep. 2015;3(2):189-194.

17. Gandini S, Gnagnarella P, Serrano D, Pasquali E, Raimondi S. Vitamin D receptor polymorphisms and cancer. Adv Exp Med Biol. 2014;810:69-105.

18. Jafari M, Pirouzi A, Anoosheh S, Farnia P, Tajik N. Rapid and simultaneous detection of vitamin $\mathrm{D}$ receptor gene polymorphisms by a single ARMS-PCR assay. Mol Diagn Ther. 2014;18(1):97-103.

19. Setiabudiawan B, Kartasasmita CB, Garna H, Parwati I, Maskoen AM. Polimorfisme FokI, BsmI, ApaI, dan TaqI Gen Reseptor Vitamin D pada Kejadian Tuberkulosis Anak. MKB. 2010;42:187.

20. Hoan NX, Khuyen N, Giang DP, Binh MT, Toan NL, Anh DT, et al. Vitamin D receptor ApaI polymorphism associated with progression of liver disease in Vietnamese patients chronically infected with hepatitis B virus. BMC Medical Genetics. 2019;20:201.

21. Ramos-Lopez E, Kurylowicz A, Bednarczuk T, Paunkovic J, Seidl C, Badenhoop K. Vitamin D receptor polymorphisms are associated with Graves' disease in German and Polish but not in
Serbian patients. Thyroid. 2005;15(10):1125-30. 22. Mohammed MA, Shabana T, Sheta NM, Omar SAM. Vitamin D Receptor Gene Polymorphisms as a Predictive Risk Factor for Hepatocellular Carcinoma Development and Severity in Chronic Hepatitis B. International Journal of Cancer Research. 2017;13(1):26-35. 23. Yao X, Zeng H, Zhang G, Zhou W, Yan Q, Dai L, et al. The associated ion between the VDR gene polymorphisms and susceptibility to hepatocellular carcinoma and the clinicopathological features in subjects infected with HBV. Biomed Res Int. 2013;2013:953974.

24. Mostafa-Hedeab G, Sabry D, Mostafa Abdelaziz G, Ewaiss M, Adli N, Fathy W. Influence of Vitamin D Receptor Gene Polymorphisms on Response to Pegylated Interferon in Chronic Hepatitis B Egyptian Patients. Rep Biochem Mol Biol. 2018;6(2):186196.

25. He Q, Huang Y, Zhang L, Yan Y, Liu J, Song $\mathrm{X}$, et al. Association between vitamin $\mathrm{D}$ receptor polymorphisms and hepatitis $\mathrm{B}$ virus infection susceptibility: A meta-analysis study. Gene. 2018;645:105-12.

26. Tangoh D, Mahmood Y, Apinjoh T, Nyingchu R, Azhar A, Achidi E. A Rapid Multiplex ARMS-PCR Method for the Detection of Four Single Nucleotide Polymorphisms of the Vitamin D Receptor (VDR) Gene. Imp J Interdiscip Res. 2017;3(9):573-80. 